RADOVI

Zavoda za znanstveni rad

HAZU Varaždin

VLADIMIR HUZJAN

Zavod za znanstveni rad HAZU, Varaždin

vhuzjan@gmail.com

ANA KANIŠKI

Varaždin

ana.kaniski@gmail.com
UDK 061.22:06.091(051)(497.523Varaždin)

Prethodno priopćenje Preliminary communication

Primljeno: 21. 11. 2016.

Prihvaćeno: 14. 06. 2017.

DOI: http://doi.org/10.21857/yrvgqtpdx9

\title{
O HRVATSKOJ AKADEMIJI, NJEZINIM RAZREDIMA \\ I ČLANOVIMA ROĐENIM NA PODRUČJU SJEVEROZAPADNE HRVATSKE. \\ U POVODU 30. OBLJETNICE TISKA ČASOPISA RADOVI ZAVODA ZA ZNANSTVENI RAD VARAŽDIN
}

\section{UVOD}

Na širem području sjeverozapadne Hrvatske, pod koju podrazumijevamo Bjelovarsko-bilogorsku, Koprivničko-križevačku, Krapinsko-zagorsku, Međimursku i Varaždinsku županiju rođene su 82 osobe koje su zahvaljujući svojem nesebičnom radu te znanstvenom i kulturno-umjetničkom doprinosu postali članovi Hrvatske akademije znanosti i umjetnosti, od njezina osnutka do kraja 2016. godine. Neki od njih postali su akademici ili redoviti članovi, dok je dio djelovao u statusu člana suradnika, dopisnog člana ili počasnog člana. Ovim radom želimo i lokalnoj zajednici ukazati na članove Hrvatske akademije koji su porijeklom s navedenog područja i ukazati na značaj njihovih života i rada za povijest, znanost, kulturu i umjetnost Republike Hrvatske. ${ }^{1}$

1 Mjerilo za odabir članova Akademije koje smo predstavili u ovom radu jest da su rođeni na širem području sjeverozapadne Hrvatske. Podaci u tablicama i grafikona odnose se isključivo na njih (op. a.). 


\section{O HRVATSKOJ AKADEMIJI I NJENIM RAZREDIMA}

U ovom radu sažeto smo predstavili povijest nastanka naše Akademije i razvoj njenih razreda unutar kojih su djelovali i danas djeluju njeni članovi. ${ }^{2}$ Utemeljitelj današnje Hrvatske akademije znanosti i umjetnosti bio je đakovačko-srijemski biskup Josip Juraj Strossmayer (Osijek, 4. II. 1815. - Đakovo, 8. III. 1905.) koji je na sjednici Banske konferencije 10. XII. 1860. potaknuo osnutak Jugoslavenske akademije znanosti i umjetnosti predavši banu Josipu Šokčeviću (Vinkovci, 7. III. 1811. - Beč, 16. XI. 1896.) zakladni list na 50.000 forinti. Uz prilog je priložio pismo u kojem je zabilježio viziju o budućoj Akademiji: “Narodna je knjiga i glavni plod duha svakog naroda i glavno promicalo njegova razvitka; pače u nesretnih okolnosti javnoga života jedino sidro, koje ga od propasti čuva". Hrvatski sabor prijedlog je jednoglasno prihvatio 29. IV. 1861. godine, a ubrzo, 29. VII. iste godine donio zaključak kojim se Akademija stavlja pod zaštitu Sabora. ${ }^{3}$ Međutim, iz političkih razloga tadašnji je car i kralj Franjo Josip I. (Beč, 18. VIII. 1830. - Beč, 21. XI. 1916.) službenu potvrdu za početak rada Akademije dao 4. III. 1866. godine. ${ }^{4}$ Nekoliko dana kasnije, Sabor je potvrdio prvih 14 članova Akademije među kojima su bila dva Varaždinca: Mirko Bogović (Varaždin, 2. II. 1816. - Zagreb, 4. V. 1893.) i Vatroslav Jagić (Varaždin, 6. VII. 1838. - Beč, 5. VIII. 1923.), dok je treći, Ivan Kukuljević Sakcinski (Varaždin, 29. V. 1816. - Puhakovec, 1. VIII. 1889.) odbio biti punopravnim članom. Dva mjeseca kasnije članovi su na svojem prvom zasjedanju izabrali utemeljitelja Josipa Jurja Strossmayera za pokrovitelja, a Franju Račkog (Fužine, 25. XI. 1828. - Zagreb, 13. II. 1894.) za prvog predsjednika Akademije. ${ }^{5}$

U Akademiji su od početka djelovala tri razreda: Historičko-filologički, Filosofičkojuridički razred i Matematičko-prirodoslovni razred, a njezini su se članovi dijelili na počasne, prave i dopisne članove. Nakon završetka Prvog svjetskog rata, 1919. osnovan je Umjetnički razred koji je tada sažimao djelatnosti s područja književnosti,

\footnotetext{
Jugoslavenska akademija znanosti i umjetnosti 1866 - 1966, red. odbor Grga Novak, Zagreb, Jugoslavenska akademija znanosti i umjetnosti, 1966. (dalje: JAZU 1866 - 1966, Zagreb, JAZU, 1966.); 120 godina Jugoslavenske akademije znanosti $i$ umjetnosti, ur. Slobodan Kaštela, Zagreb, Jugoslavenska akademija znanosti i umjetnosti, 1986. (dalje: 120 godina JAZU, Zagreb, JAZU, 1986.); Jakov SIROTKOVIĆ, 125 godina Jugoslavenske akademije znanosti i umjetnosti, ur. Hrvoje Požar, Zagreb, Jugoslavenska akademija znanosti i umjetnosti, 1991. (dalje: 125 godina JAZU, Zagreb, JAZU, 1991.); 140 godina Hrvatske akademije znanosti i umjetnosti 1861. - 2001., gl. ur. Milan Moguš, Zagreb, Hrvatska akademija znanosti i umjetnosti, 2001. (dalje: 140 godina JAZU 1861. - 2001., Zagreb, HAZU, 2001.); HAZU: 150 godina Hrvatske akademije znanosti i umjetnosti 1861. - 2011., gl. ur. Franjo Šanjek, Zagreb, Hrvatska akademija znanosti i umjetnosti, 2011. (dalje: 150 godina HAZU 1861. - 2011., Zagreb, HAZU, 2011.). Za preuzimanje podataka i analizu koristili smo i Akademijine periodične publikacije poput časopisa Rad ili Ljetopis.

3150 godina HAZU 1861. - 2011., Zagreb, HAZU, 2011., 14.

4 Ibidem.

5 Ibidem, 15.; 120 godina JAZU, Zagreb, JAZU, 1986., 19.
} 
likovnih umjetnosti i glazbe. ${ }^{6}$ Jugoslavenska akademija je tijekom Drugog svjetskog rata u vrijeme postojanja Nezavisne Države Hrvatske ukinuta, a ubrzo je 1941. godine osnovana Hrvatska akademija znanosti i umjetnosti. Historičko-filologički razred promijenio je ime u Poviestno-jezikoslovni razred, Filosofičko-juridički u Filozofskopravni razred, a preostali su razredi zadržali ranije nazive. ${ }^{7}$ Antifašističko vijeće narodnog oslobođenja Jugoslavije je pred kraj Drugog svjetskog rata (3. II. 1945.) ukinulo HAZU. Dva mjeseca kasnije pristupilo se obnovi Jugoslavenske akademije znanosti i umjetnosti. U travnju 1946. imenovan je privremeni odbor koji je potvrdio neke članove iz razreda prvotne JAZU, a u veljači 1947. izabrao je nove. U obnovi Akademije preustrojeni su njezini razredi i uvedena je nova kategorija članstva dopisnog člana u radnom sastavu. ${ }^{8}$

Određene djelatnosti iz područja koje su dotad pripadale u Historičko-filologički i Filosofičko-juridički razred izdvojene su u Odjel za filozofiju i društvene nauke. Prvotni Matematičko-prirodoslovni razred razdijeljen je na Odjel za matematičke, fizičke i tehničke nauke i Odjel za prirodne i medicinske nauke. Umjetnički razred razdijeljen je na Odjel za jezik i knjižeonost (u koji su dijelom ušli filolozi iz Historičko-filologičkog razreda) i Odjel za umjetnost koji je iduće, 1948. preimenovan u Odjel za likovne umjetnosti i muziku. Početkom 1950-ih preimenovano je i razdvojeno nekoliko odjela: Odjel za filozofiju $i$ društvene nauke postao je Odjel za društvene nauke, zatim Odjel za prirodne i medicinske nauke 19. VIII. 1950. razdijeljen je na Odjel za prirodne nauke i Odjel za medicinske nauke, 16. X. 1951. iz Odjela za jezik i književnost nastali su Odjel za filologiju i Odjel za suvremenu knjižeonost, a 18. III. 1953. iz Odjela za likoone umjetnosti i muziku ustrojeni su Odjel za likovnu umjetnost i Odjel za muziku koji je već 1955. preimenovan u Odjel za muzičku umjetnost.

Dodatne promijene uslijedile su 1970-ih i 1980-ih godina. Zakonskom odredbom od 29. XII. 1971. uređene su kategorije članstva u Akademiji. Pravi član ustupio je mjesto redovitom članu (ili akademiku), dopisni član u radnom sastavu postao je izvanredni član, a suradnik je postao član suradnik. ${ }^{9}$ Kategorije su doživotne osim za članove suradnike koji podliježu izboru svakih deset godina. Akademijinih osam razreda 1972. promijenili su svoje nazive zamijenivši riječi odjel i nauke riječima razred i znanosti. Godine 1985. tri su razreda proširila znanstveni rad: Razred za matematičke, fizičke i tehničke znanosti postao je Razred za matematičke, fizičke, kemijske i tehničke znanosti, Razred za filologiju postao je Razred za filološke znanosti i Razred za suvremenu književnost proširenjem je postao Razred za književnost.

150 godina HAZU 1861. - 2011., Zagreb, HAZU, 2011., 198.

Ibidem, 20.; 140 godina JAZU 1861. - 2001., Zagreb, HAZU, 2001., 18.

150 godina HAZU 1861. - 2011., Zagreb, HAZU, 2011., 20-21.

Ibidem, 73, 22. 
Pod prvotnim je imenom Akademija djelovala do početka 1990-ih. Tada je zakonom od 24. VII. 1991. godine osnovana Hrvatska akademija znanosti i umjetnosti, najviša znanstvena i umjetnička ustanova u Republici Hrvatskoj, koja nastavlja rad i pravni je slijednik Jugoslavenske akademije (1861. - 1941.; 1945. - 1991.) i Hrvatske akademije znanosti i umjetnosti (1941. - 1945.). Njezina glavna zadaća je da: “[...] potiče i organizira znanstveni rad i zalaže se za primjenu postignutih rezultata, razvija umjetničku i kulturnu djelatnost i brine o hrvatskoj kulturnoj baštini i njezinoj afirmaciji u svijetu". ${ }^{10}$ Akademija je 1996. imala osam razreda. Njima je 27. IX. 1997. godine pridružen deveti Razred za tehničke znanosti koji je nastao izdvajanjem iz postojećeg Razreda za matematičke, fizičke, kemijske i tehničke znanosti. Godine 1996. utvrđene su četiri kategorije članstva: redoviti član, počasni član, dopisni član i član suradnik.

Akademijina znanstvena i umjetnička djelatnost danas je organizirana u devet razreda, čija numeracija prati njihov kronološki osnutak: I. Razred za društvene znanosti, II. Razred za matematičke, fizičke i kemijske znanosti, III. Razred za prirodne znanosti, IV. Razred za medicinske znanosti, V. Razred za filološke znanosti, VI. Razred za knjižeonost, VII. Razred za likowne umjetnosti, VIII. Razred za glazbenu umjetnost $i$ muzikologiju i IX. Razred za tehničke znanosti. Povijesni razvoj današnjih Akademijinih razreda, od njezina osnutka 1861. do danas, prikazan je u Tablici $1 .{ }^{11}$

\section{O HRVATSKOJ AKADEMIJI I NJEZINIM ČLANOVIMA ROĐENIM NA PODRUČJU SJEVEROZAPADNE HRVATSKE}

Na temelju provedenog istraživanja možemo kazati kako od svojega osnutka do kraja 2016. godine Akademija broji ukupno 82 člana rođena na širem području sjeverozapadne Hrvatske. Najbrojniji su iz Varaždinske županije (26), zatim iz Koprivničko-križevačke i Krapinsko-zagorske županije (18), slijedi Bjelovarskobilogorska županija (13) te na kraju Međimurska županija (7) (vidi Tablicu 2 i Grafikon 1). Od ukupnog broja članova, 64 su preminula, a 18 je u vrijeme pisanja ovog rada živih (vidi Grafikon 4). Podsjećamo da od ukupnog broja članova njih 80 su muškarci, a samo dvije su žene (vidi Grafikon 5).

Članovi Hrvatske akademije sa šireg područja sjeverozapadne Hrvatske najviše su zastupljeni u VII. Razredu za likovne umjetnosti (15) i I. Razredu za društvene znanosti (14), slijedi VI. Razred za knjižeunost (12), III. Razred za prirodne znanosti (10), IV. Razred za medicinske znanosti (9), V. Razred za filološke znanosti (8). Potom slijede VIII. Razred za

$10 \quad$ Ibidem, 26.

11 Tablica 1 izrađena je prema podacima iz pet dostupnih spomenica Akademije (vidi bilješku br. 1). 
glazbenu umjetnost i muzikologiju (7), II. Razred za matematičke, fizičke i kemijske znanosti (6) i IX. Razred za tehničke znanosti (1) (vidi Tablicu 3 i Grafikon 2).

S obzirom na višestruk izbor u članstvo Akademije, članove smo svrstali prema mjerilu posljednjeg članstva, primjerice izvanredni član Lujo Margetić (Donja Stubica, 18. X. 1920. - Rijeka, 17. V. 2010.) 24. VIII. 1991. godine imenovan je za redovitog člana. Neki članovi Akademije djelovali su u više znanstvenih područja, odnosno u onima koja danas pripadaju različitim razredima. Stoga smo primjerice pravnika i diplomata Milorada Stražnickog (Križevci, 19. IX. 1879. - Rijeka, 30. VII. 1958.), člana Filosofičko-juridičkog razreda svrstali u Razred za književnost jer je ostavio značajniji trag djelujući kao književnik Milo Mistra.

Prema kategoriji članstva najbrojniji su akademici odnosno pravi/ redoviti članovi (43), slijede dopisni članovi izvan radnog sastava/ dopisni članovi (18), zatim suradnici/ članovi suradnici (12), počasni članovi (5) te dopisni članovi u radnom sastavu/ izvanredni članovi (4) (vidi Tablicu 4 i grafikon 3). ${ }^{12}$

\section{ZAVODI HRVATSKE AKADEMIJE NA ŠIREM PODRUČJU SJEVEROZAPADNE HRVATSKE}

Osnovna djelatnost Akademijinih regionalnih Zavoda jest interdisciplinaran znanstveno-istraživački rad usmjeren na teme važne za lokalnu zajednicu, a vođen je mjerilima Akademije. U tom smislu Zavodi pokreću, organiziraju ili koordiniraju rad znanstvenih skupova, okruglih stolova, predavanja i drugih znanstveno-kulturnih aktivnosti o temama važnim za širi prostor u kojem djeluju. Jedan od konačnog oblika rada Zavoda jest i tisak prigodne monografije, časopisa ili zbornika radova.

$\mathrm{Na}$ širem području sjeverozapadne Hrvatske aktivno djeluju tri Akademijina Zavoda:

1) Zavod za znanstveni rad Hrvatske akademije znanosti i umjetnosti u Varaždinu osnovan je 1983. godine. ${ }^{13} \mathrm{U}$ vrijeme pisanja ovog rada Zavod se nalazi u prostorijama palače Keglević, Vladimira Nazora 14, u Varaždinu. Voditelji Zavoda bili su akademik Andre Mohorovičić (1983. - 2002.), akademik Miroslav Šicel (2003.

12 S obzirom na povijesni razvoj kategorija članstva u Akademiji, zadržali smo njihovo dvostruko nazivlje: prvotni naziv kategorije članstva koja je nekoć postojala odijeljen je kosom crtom od današnjeg naziva, izuzev kategorije izvanrednog člana koja se više ne dodjeljuje, jer ju je zamijenila kategorija dopisnog člana.

13 Više o varaždinskom Zavodu vidi u: Slobodan KAŠTELA, "Trideset godina nakladničke djelatnosti Zavoda za znanstveni rad Hrvatske akademije znanosti i umjetnosti u Varaždinu", u Bibliografija nakladničke djelatnosti Zavoda za znanstveni rad Hrvatske akademije znanosti i umjetnosti u Varaždinu (1983. -2012.), Hrvatska akademija znanosti i umjetnosti, Zavod za znanstveni rad u Varaždinu, Zagreb - Varaždin, 2013., 7-9. 
- 2011.) te akademik Stjepan Damjanović koji navedenu dužnost obavlja od 2012. godine. Upravitelji Zavoda bili su prof. emeritus Franjo Ruža (1983. - 1993.), mr. sc. Ivan Grabar (1993. - 1994.), mr. sc. Eduard Vargović (1994. - 2013.) te dr. sc. Vladimir Huzjan koji navedenu dužnost obavlja od 2014. godine. Administrativna tajnica Zavoda je Ljiljana Biškup.

2) Zavod za znanstvenoistraživački i umjetnički rad u Bjelovaru osnovan je 2005. godine. ${ }^{14} \mathrm{U}$ vrijeme pisanja ovog rada Zavod se nalazi na adresi Antuna Branka Šimića 1/ 1 u Bjelovaru. Voditelj Zavoda je prof. dr. sc. Slobodan Kaštela, član suradnik Hrvatske akademije, a upravitelj je prof. dr. sc. Vladimir Strugar. Administrativna tajnica Zavoda je Sandra Kljajić.

3) Zavod za znanstvenoistraživački i umjetnički rad Koprivničko-križevačke županije u Križevcima osnovan je 2013. godine. U vrijeme pisanja ovog rada Zavod se nalazi na adresi Ivana Zakmardija Dijankovečkoga 3 u Križevcima. Voditelj Zavoda je akademik Franjo Tomić, a upravitelj je dr. sc. Ivo Peklić.

14 Više o bjelovarskom Zavodu vidi u: Slobodan KAŠTELA, "Deset godina od osnivanja Zavoda za znanstvenoistraživački i umjetnički rad Hrvatske akademije znanosti i umjetnosti u Bjelovaru (2005. 2015.)", Josip Juraj Strossmayer i Bjelovar: trajna prisutnost. 200. godišnjica rođenja Josipa Jurja Strossmayera i 10. godišnjica osnivanja Zavoda za znanstvenoistraživački $i$ umjetnički rad Hrvatske akademije znanosti $i$ umjetnosti u Bjelovaru, Zagreb - Bjelovar, 2015., 21-26. 


\begin{tabular}{|c|c|c|c|c|c|c|c|c|c|c|}
\hline 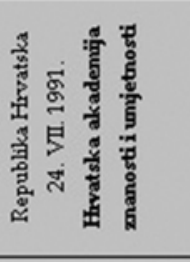 & 孞 & 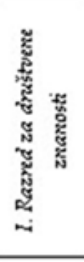 & 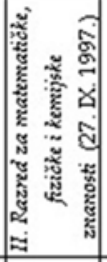 & 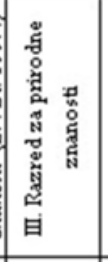 & 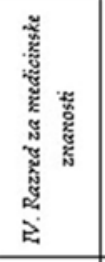 & 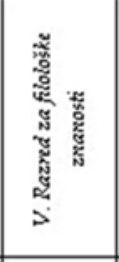 & 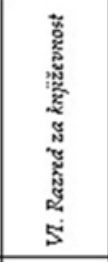 & 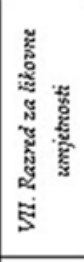 & 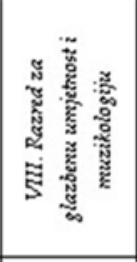 & 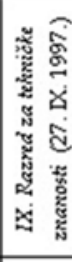 \\
\hline \multirow{4}{*}{ 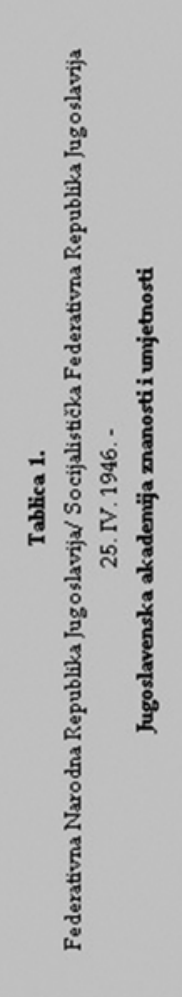 } & 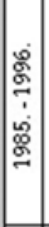 & 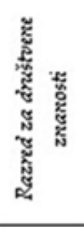 & 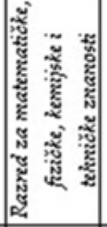 & 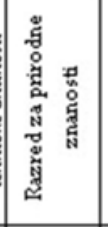 & 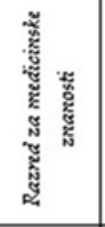 & 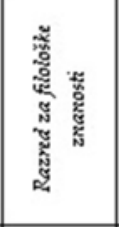 & 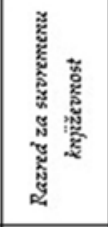 & 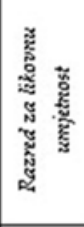 & 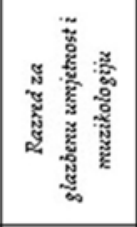 & \\
\hline & 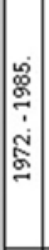 & 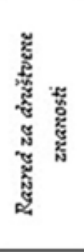 & 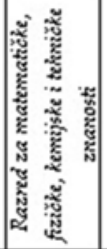 & 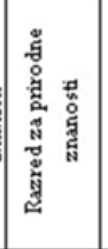 & 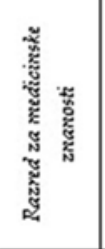 & 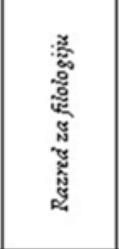 & 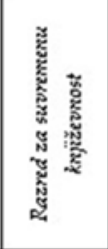 & 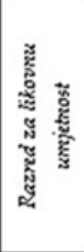 & 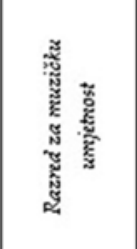 & \\
\hline & 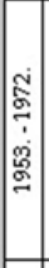 & 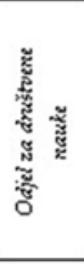 & 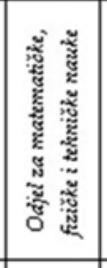 & 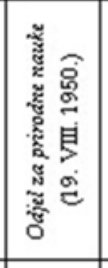 & 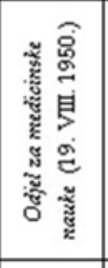 & 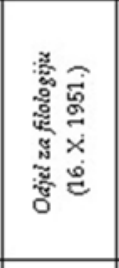 & 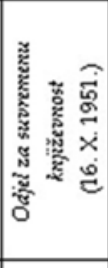 & 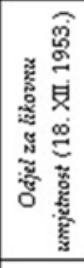 & 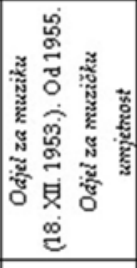 & \\
\hline & 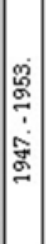 & 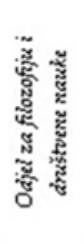 & 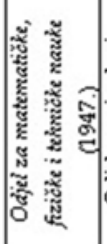 & 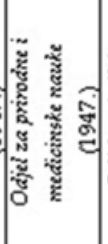 & 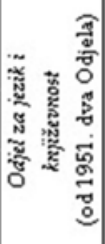 & 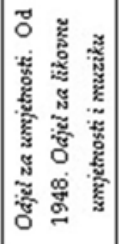 & & & & \\
\hline 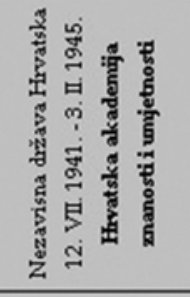 & & 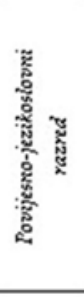 & 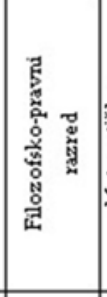 & 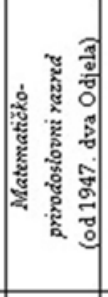 & 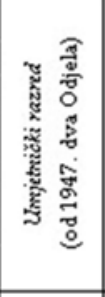 & & & & & \\
\hline 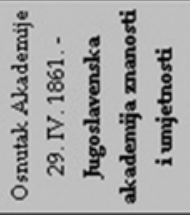 & & 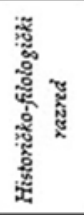 & 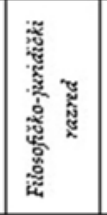 & 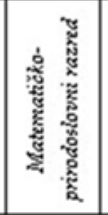 & 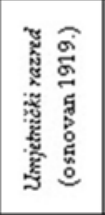 & & & & & \\
\hline
\end{tabular}


Tablica 2. Podjela članova Akademije prema županiji rođenja Napomena: P - preminuli članovi; ž - živi članovi (u vrijeme pisanja ovog rada)

\begin{tabular}{|c|c|c|}
\hline Županija & Član & ovi Akademije \\
\hline $\begin{array}{l}\text { Bjelovarsko- } \\
\text { bilogorska }\end{array}$ & $P$ & $\begin{array}{l}\text { Vlado Antolić, Vojin Bakić, Tomo Bosanac, Ivan Dončević, Zvonimir Janko, } \\
\text { Edo Murtić, Boris Petz, Branko Souček, Anton Švajger, Ivan Trnski }\end{array}$ \\
\hline (13 članova) & ž & Vladimir Marković, Goran Tribuson, Vladimir Volenec \\
\hline $\begin{array}{l}\text { Koprivničko- } \\
\text { križevačka } \\
\text { županija }\end{array}$ & $P$ & $\begin{array}{l}\text { Marijan Detoni, Franjo Fancev, Karlo Horvat, Franjo pl. Marković, } \\
\text { Andre Mohorovičić, Ivo Pevalek, Ivan Sabolić, Milorad Stražnicky, Teodor Varićak, } \\
\text { Vladimir Vrkljan, Pavao Vuk-Pavlović }\end{array}$ \\
\hline & $\check{z}$ & $\begin{array}{l}\text { Dragutin Feletar, Ivan Golub, Drago Grdenić, Čedomil Lucu, Stanislav Marijanović, } \\
\text { Mladen Obad-Šćitaroci, Milivoj Solar }\end{array}$ \\
\hline $\begin{array}{l}\text { Krapinsko- } \\
\text { zagorska } \\
\text { županija } \\
\text { (18 članova) }\end{array}$ & $P$ & $\begin{array}{l}\text { Antun Augustinčić, Ivan Broz, Josip Broz Tito, Franjo Dugan st., Rudolf Filipović, Mirko } \\
\text { Dražen Grmek, Ćiril Metod Iveković, Franjo Iveković, Oton Iveković, Janko Leskovar, } \\
\text { Lujo Margetić, Viktor Novak, Božidar Oklješa, Antun Polanšćak, Josip Seissel, Franjo } \\
\text { Tuđman, Rudolf Valdec }\end{array}$ \\
\hline & ž & August Kovačec \\
\hline Međimurska & $P$ & Arpad Hahn, Antun Magdalenić, Stjepan Šćavničar, Vinko Žganec \\
\hline (7 članova) & $\check{z}$ & Anđela Frančić, Josip Madić, Stanislav Tuksar \\
\hline $\begin{array}{l}\text { Varaždinska } \\
\text { županija } \\
\text { (26 članova) }\end{array}$ & $P$ & $\begin{array}{l}\text { Gjuro Arnold, Ivo Babić, Antun Bauer, Mirko Bogović, Stjepan Bratko, Mladen Hajsig, } \\
\text { Lavoslav Horvat, Stjepan Horvatić, Vatroslav Jagić, Zlatko Janković, Ivan Kukuljević } \\
\text { Sakcinski, Mirko Malez, Jurica Murai, Zlatko Pepeonik, Mirko Rački, Vjekoslav } \\
\text { Rosenberg-Ružić, Ladislav Šaban, Tomislav Janko Šagi-Bunić, Miroslav Šicel, Pavao } \\
\text { Štern, Franjo Švelec, Josip Tišljar, Ivo Tomašec }\end{array}$ \\
\hline & $\check{z}$ & Mario Grčević, Ruža Pospiš-Baldani, Franjo Šanjek \\
\hline
\end{tabular}


Tablica 3. Podjela članova Akademije prema članstvu u razredima

\begin{tabular}{|c|c|}
\hline Razred & Članovi Akademije \\
\hline $\begin{array}{l}\text { I. Razred za } \\
\text { društvene znanosti } \\
\text { (15 članova) }\end{array}$ & $\begin{array}{l}\text { Historičko-filologički razred: Karlo Horvat } \\
\text { Filosofičko-juridički razred: Gjuro Arnold, Antun Bauer, Mirko Bogović } \\
\text { Ivan Kukuljević Sakcinski, Franjo pl. Marković, Pavao Vuk-Pavlović } \\
\text { Odjel za filozofiju i društvene naukel Odjel za društvene naukel } \\
\text { Razred za društvene znanosti: Stjepan Bratko, Josip Broz Tito, Dragutin Feletar, Lujo } \\
\text { Margetić, Viktor Novak, Tomislav Janko Šagi-Bunić, Franjo Šanjek, Franjo Tuđman }\end{array}$ \\
\hline $\begin{array}{l}\text { II. Razred za } \\
\text { matematičke, } \\
\text { fizičke } \\
\text { i kemijske znanosti } \\
\text { (6 članova) }\end{array}$ & $\begin{array}{l}\text { Odjel za matematičke, fizičke i tehničke nauke: Drago Grdenić, Zlatko Janković, Vladimir } \\
\text { Vrkljan } \\
\text { Razred za matematičke, fizičke i tehničke znanosti: Branko Souček, Vladimir Volenec } \\
\text { Razred za matematičke, fizičke, kemijske i tehničke znanosti: Zvonimir Janković }\end{array}$ \\
\hline $\begin{array}{l}\text { III. Razred za } \\
\text { prirodne znanosti } \\
\text { (10 članova) }\end{array}$ & $\begin{array}{l}\text { Matematičko-prirodoslovni razred: Ivo Pevalek } \\
\text { Odjel za prirodne i medicinske nauke: Stjepan Horvatić } \\
\text { Odjel za prirodne nauke / Razred za prirodne znanosti: Čedomil Lucu, } \\
\text { Antun Magdalenić, Mirko Malez, Zlatko Pepeonik, Boris Petz, Stjepan Šćavničar, Anton } \\
\text { Švajger, Josip Tišljar }\end{array}$ \\
\hline $\begin{array}{l}\text { IV. Razred za } \\
\text { medicinske } \\
\text { znanosti } \\
\text { (9 članova) }\end{array}$ & $\begin{array}{l}\text { Odjel za prirodne i medicinske nauke: Ivo Babić } \\
\text { Odjel za medicinske nauke / Razred za medicinske nauke: Mirko Dražen Grmek, Arpad } \\
\text { Hahn, Mladen Hajsig, Josip Madić, Božidar Oklješa, Pavao Štern, Ivo Tomašec, Teodor } \\
\text { Varićak }\end{array}$ \\
\hline $\begin{array}{l}\text { V. Razred za } \\
\text { filološke znanosti } \\
\text { (8 članova) }\end{array}$ & $\begin{array}{l}\text { Historičko-filologički razred / Povijesno-jezikoslovni razred: Ivan Broz, } \\
\text { Rudolf Filipović, Franjo Iveković, Vatroslav Jagić } \\
\text { Odjel za jezik i književnost/ Odjel za filologiju/ Razred za filologiju/ } \\
\text { Razred za filološke znanosti: Anđđela Frančić, Mario Grčević, August Kovačec, Franjo } \\
\text { Švelec }\end{array}$ \\
\hline $\begin{array}{l}\text { VI. Razred za } \\
\text { književnost } \\
\text { (11 članova) }\end{array}$ & $\begin{array}{l}\text { Historičko-filologički razred: Franjo Fancev } \\
\text { Filosofičko-juridički razred: Milorad Stražnicky, Ivan Trnski } \\
\text { Umjetnički razred: Janko Leskovar } \\
\text { Odjel za jezik i književnost: Ivan Dončević } \\
\text { Odjel za suvremenu književnost/ Razred za suvremenu književnost/ } \\
\text { Razred za književnost: Ivan Golub, Stanislav Marijanović, Antun Polanšćak, Milivoj Solar, } \\
\text { Miroslav Šicel, Goran Tribuson }\end{array}$ \\
\hline $\begin{array}{l}\text { VII. Razred za } \\
\text { likovne umjetnosti } \\
\text { (15 članova) }\end{array}$ & $\begin{array}{l}\text { Umjetnički razred: Antun Augustinčić, Ćiril Metod Iveković, Oton Iveković, Mirko Rački, } \\
\text { Rudolf Valdec } \\
\text { Odjel za umjetnost / Odjel za likovne umjetnosti i muziku: Lavoslav Horvat, } \\
\text { Josip Seissel } \\
\text { Odjel za likovnu umjetnost / Razred za likovnu umjetnost / Razred za likovne umjetnosti: } \\
\text { Vlado Antolić, Vojin Bakić, Marijan Detoni, Vladimir Marković, Andre Mohorovičić, Edo } \\
\text { Murtić, Mladen Obad Šćtaroci, Ivan Sabolić }\end{array}$ \\
\hline $\begin{array}{l}\text { VIII. Razred za } \\
\text { glazbenu umjetnost } \\
\text { i muzikologiju } \\
\text { (7 članova) }\end{array}$ & $\begin{array}{l}\text { Umjetnički razred: Franjo Dugan st., Vjekoslav Rosenberg-Ružić } \\
\text { Odjel za umjetnost / Odjel za likovne umjetnosti i muziku: Vinko Žganec } \\
\text { Odjel za muziku / Odjel za muzičku umjetnost / Razred za muzičku umjetnost / } \\
\text { Razred za glazbenu umjetnost i muzikologiju: Jurica Murai, Ruža Pospiš-Baldani, Stanislav } \\
\text { Tuskar, Ladislav Šaban }\end{array}$ \\
\hline $\begin{array}{l}\text { IX. Razred za } \\
\text { tehničke znanosti } \\
\text { (1 član) }\end{array}$ & Odjel za matematičke fizičke i tehničke nauke: Tomo Bosanac \\
\hline
\end{tabular}


Tablica 4. Podjela članova Akademije prema vrsti članstva

P - preminuli članovi; Ž - živi članovi (u vrijeme pisanja ovog rada)

\begin{tabular}{|c|c|c|}
\hline Članstvo & & novi Akademije \\
\hline $\begin{array}{l}\text { Počasni član } \\
\text { (5 osoba) }\end{array}$ & $P$ & $\begin{array}{l}\text { Antun Bauer, Josip Broz Tito, Franjo Iveković, Ivan Kukuljević Sakcinski, } \\
\text { Ivan Trnski }\end{array}$ \\
\hline $\begin{array}{l}\text { Akademik/ } \\
\text { pravi / } \\
\text { redovni član } \\
\text { (44 osobe) }\end{array}$ & $P$ & $\begin{array}{l}\text { Gjuro Arnold, Antun Augustinčić, Ivo Babić, Vojin Bakić, Tomo Bosanac, } \\
\text { Marijan Detoni, Franjo Dugan st., Franjo Fancev, Dragutin Feletar, Rudolf Filipović, } \\
\text { Lavoslav Horvat, Stjepan Horvatić, Ćiril Metod Iveković, Vatroslav Jagić, Zlatko Janković, } \\
\text { Mirko Malez, Lujo Margetić, Franjo pl. Marković, Andre Mohorovičić, Jurica Murai, } \\
\text { Edo Murtić, Božidar Oklješa, Ivo Pevalek, Mirko Rački, Josip Seissel, Stjepan Ščavnićar, } \\
\text { Miroslav Šicel, Anton Švajger, Franjo Švelec, Josip Tišljar, Ivo Tomašec, Franjo Tuđman, } \\
\text { Rudolf Valdec, Teodor Varićak, Vinko Žganec }\end{array}$ \\
\hline & Ž & $\begin{array}{l}\text { Drago Grdenić, August Kovačec, Josip Madić, Vladimir Marković, } \\
\text { Mladen Obad-Š́́itaroci, Milivoj Solar, Franjo Šanjek, Goran Tribuson, } \\
\text { Stanislav Tuskar }\end{array}$ \\
\hline Dopisni član u & $P$ & Ivan Dončević, Arpad Hahn, Ivan Sabolić, Ladislav Šaban \\
\hline $\begin{array}{l}\text { radnom } \\
\text { sastavu / } \\
\text { izvanredni član } \\
\text { (4 osobe) }\end{array}$ & & \\
\hline $\begin{array}{l}\text { Dopisni član } \\
\text { izvan radnog } \\
\text { sastava / } \\
\text { dopisni član }\end{array}$ & $P$ & $\begin{array}{l}\text { Vlado Antolić, Mirko Bogović, Ivan Broz, Mirko Dražen Grmek, Karlo Horvat, } \\
\text { Oton Iveković, Janko Leskovar, Viktor Novak, Vjekoslav Rosenberg-Ružić, } \\
\text { Branko Souček, Milorad Stražnicky, Tomislav Janko Šagi-Bunić, Pavao Štern, Vladimir } \\
\text { Volenec, Pavao Vuk-Pavlović }\end{array}$ \\
\hline & Ž & Ivan Golub, Zvonimir Janko, Ruža Pospiš-Baldani \\
\hline $\begin{array}{l}\text { Suradnik / } \\
\text { član suradnik }\end{array}$ & $P$ & $\begin{array}{l}\text { Stjepan Bratko, Mladen Hajsig, Antun Magdalenić, Boris Petz, Antun Polanšćak, Zlatko } \\
\text { Pepeonik }\end{array}$ \\
\hline & Ž & Anđela Frančić, Mario Grčević, Čedomil Lucu, Stanislav Marijanović, Vladimir Volenec \\
\hline
\end{tabular}

\section{Grafikon 1. Podjela članova Akademije prema} rođenju (županiji) Bjelovarsko-

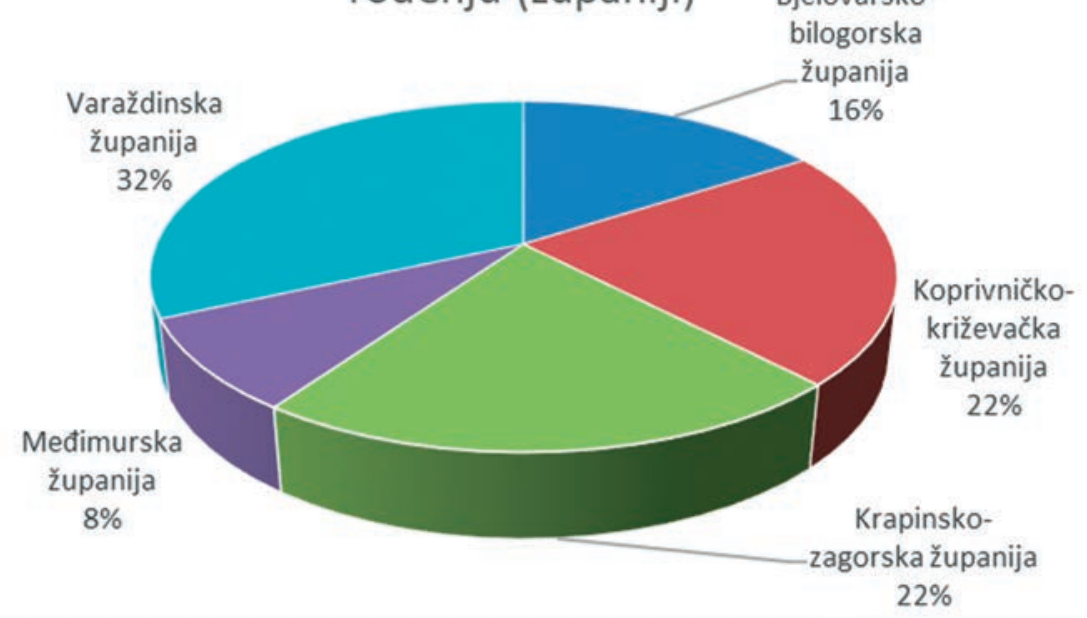



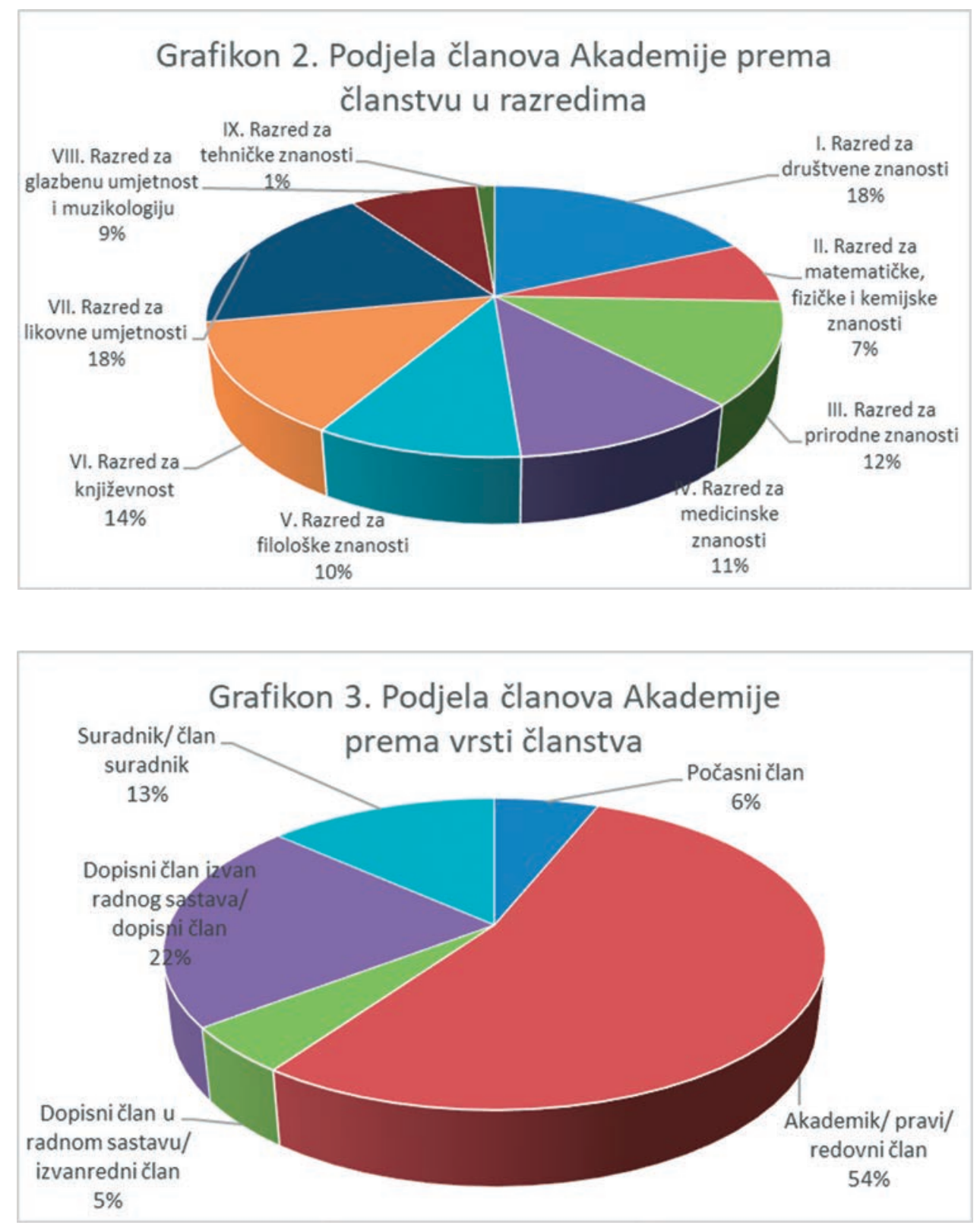


\section{Grafikon 4. Podjela članova Akademije na preminule i žive (u vrijeme pisanja rada)}

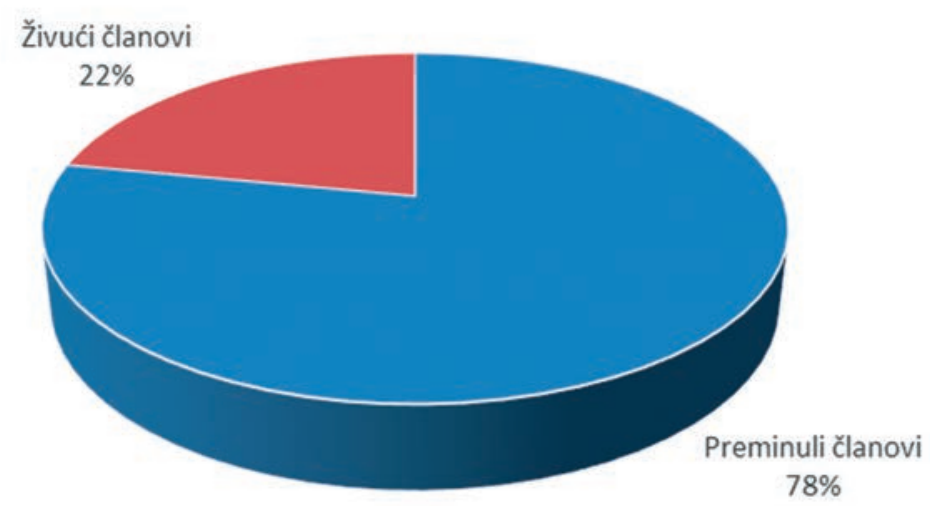

\section{Grafikon 5. Podjela članova Akademije} prema spolu Ženskičlanovi $2 \%$

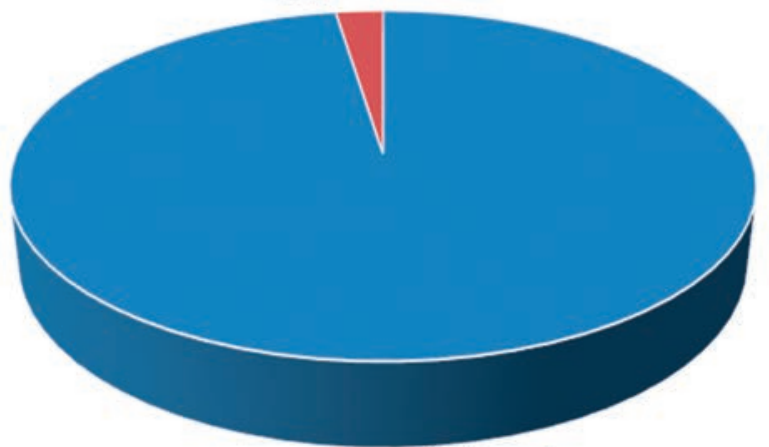

Muški članovi $98 \%$ 


\section{BIBLIOGRAFIJA}

1. Jugoslavenska akademija znanosti i umjetnosti 1866 - 1966, red. odbor Grga Novak, Zagreb, Jugoslavenska akademija znanosti i umjetnosti, 1966.

2. 120 godina Jugoslavenske akademije znanosti $i$ umjetnosti, ur. Slobodan Kaštela, Zagreb, Jugoslavenska akademija znanosti i umjetnosti, 1986.

3. Jakov SIROTKOVIĆ, 125 godina Jugoslavenske akademije znanosti $i$ umjetnosti, ur. Hrvoje Požar, Zagreb, Jugoslavenska akademija znanosti i umjetnosti, 1991.

4. 140 godina Hrvatske akademije znanosti $i$ umjetnosti 1861. - 2001., gl. ur. Milan Moguš, Zagreb, Hrvatska akademija znanosti i umjetnosti, 2001.

5. HAZU: 150 godina Hrvatske akademije znanosti i umjetnosti 1861. - 2011., gl. ur. Franjo Šanjek, Zagreb, Hrvatska akademija znanosti i umjetnosti, 2011.

6. Slobodan KAŠTELA, "Trideset godina nakladničke djelatnosti Zavoda za znanstveni rad Hrvatske akademije znanosti i umjetnosti u Varaždinu', u Bibliografija nakladničke djelatnosti Zavoda za znanstveni rad Hrvatske akademije znanosti i umjetnosti u Varaždinu (1983. - 2012.), Hrvatska akademija znanosti i umjetnosti, Zavod za znanstveni rad u Varaždinu, Zagreb - Varaždin, 2013., 7-9.

7. Slobodan KAŠTELA, "Deset godina od osnivanja Zavoda za znanstvenoistraživački i umjetnički rad Hrvatske akademije znanosti i umjetnosti u Bjelovaru (2005. - 2015.)", Josip Juraj Strossmayer i Bjelovar: trajna prisutnost. 200. godišnjica rođenja Josipa Jurja Strossmayera i 10. godišnjica osnivanja Zavoda za znanstvenoistraživački i umjetnički rad Hrvatske akademije znanosti i umjetnosti u Bjelovaru, Zagreb - Bjelovar, 2015., 21-26.

8. Za preuzimanje podataka i analizu korištene su Akademijine periodične publikacije poput časopisa Rad ili Ljetopis.

\section{SAŽETAK}

\section{O HRVATSKOJ AKADEMIJI, NJEZINIM RAZREDIMA I ČLANOVIMA ROĐENIM NA PODRUČJU SJEVEROZAPADNE HRVATSKE. U POVODU 30. OBLJETNICE TISKA ČASOPISA RADOVI ZAVODA ZA ZNANSTVENI RAD VARAŽDIN}

$\mathrm{Na}$ području sjeverozapadne Hrvatske, pod koju podrazumijevamo Bjelovarskobilogorsku, Koprivničko-križevačku, Krapinsko-zagorsku, Međimursku i Varaždinsku županiju rođene su ukupno 82 osobe koje su zahvaljujući svojem nesebičnom radu te znanstvenom i kulturno-umjetničkom doprinosu postali članovi Hrvatske akademije znanosti i umjetnosti, od njezina osnutka do kraja 2016. godine. Najbrojniji su članovi iz Varaždinske 
županije, podjednako iz Koprivničko-križevačke i Krapinsko-zagorske županije, slijedi Bjelovarsko-bilogorska županija, a najmanje ih je iz Međimurske županije. Zastupljeni su svim Akademijinim razredima; najviše ih je u Razredu za likovne umjetnosti, a samo jedan član u Razredu za tehničke znanosti. Neki od njih postali su akademici ili redoviti članovi, dok je dio djelovao u statusu člana suradnika, dopisnog člana ili počasnog člana. Od ukupnog broja članova, 64 su preminula, a 18 je u vrijeme pisanja ovog rada živih. Također, od ukupnog broja članova njih 80 su muškarci, a samo dvije su žene. Ovim radom želimo i lokalnoj zajednici ukazati na članove Hrvatske akademije koji su porijeklom s navedenog područja i ukazati na značaj njihovih života i rada za povijest, znanost, kulturu i umjetnost Republike Hrvatske. Na području sjeverozapadne Hrvatske danas djeluju tri Akademijina zavoda: Zavod za znanstveni rad Hrvatske akademije znanosti i umjetnosti u Varaždinu, Zavod za znanstvenoistraživački i umjetnički rad u Bjelovaru i Zavod za znanstvenoistraživački i umjetnički rad Koprivničko-križevačke županije u Križevcima.

Ključne riječi: akademici; dopisni članovi; članovi suradnici; sjeverozapadna Hrvatska; Hrvatska akademija znanosti i umjetnosti; Akademijini Zavodi.

\section{SUMMARY}

\section{ABOUT THE CROATIAN ACADEMY, ITS DEPARTMENTS, AND MEMBERS BORN IN THE NORTHWEST OF CROATIA. ON THE 30TH ANNIVERSARY OF THE PAPERS OF THE INSTITUTE FOR SCIENTIFIC RESEARCH WORK IN VARAŽDIN}

As many as 82 people whose exceptional scientific and artistic contributions earned them a place in the Croatian Academy of Sciences and Arts were born in the Northwest of Croatia, a region which includes the counties of Bjelovar-Bilogora, Koprivnica-Križevci, Krapina-Zagorje, Međimurje and Varaždin. Most of those Academy members hail from the Varaždin County and approximately the same number from Koprivnica-Križevci and Krapina-Zagorje counties, followed closely by the Bjelovar-Bilogora County, with the fewest of them being native to the Međimurje County. They are represented in all of the Academy's departments; most of them are members of the Department of Fine Arts, while only one of them is a member of the Department of Technical Sciences. A number of them hold the title of academician or full member of the Academy, while others are associate, honorary or corresponding members. At the time of the writing of this article, of the total number of Academy members from the Northwest of Croatia, 64 are deceased, while 18 are living. Additionally, 80 of that number are men, while only 2 are women. The goal of this paper is to raise the awareness of the significance of their contributions for Croatian history, science, culture and art in the local community. There are three Academy institutes active in the northwest of Croatia,: the Institute for Scientific Work of the Croatian Academy of Sciences and Arts in Varaždin, the Institute for Scientific and Artistic Work in Bjelovar, and the Institute for Scientific Research and Artistic Work of the Koprivnica-Križevci County in Križevci.

Key Words: academicians; corresponding members; associate members; the northwest of Croatia; Croatian academy of Sciences and Arts. 